\title{
Maternal Diabetes and Deafness Syndrome
}

National Cancer Institute

\section{Source}

National Cancer Institute. Maternal Diabetes and Deafness Syndrome. NCI Thesaurus.

Code C130996.

A maternally inherited condition characterized by diabetes and sensorineural deafness with onset after the age of 20 , caused by mutation(s) in one of several mitochondrial genes, most frequently the MT-TL1 gene, which encodes the mitochondrial transfer RNA for leucine. Some patients may have additional features observed in mitochondrial disorders, including pigmentary retinopathy, ptosis, cardiomyopathy, myopathy, renal problems, and neuropsychiatric symptoms. 